\title{
Coronacrisis en fraude: vier mogelijke relaties
}

\author{
Clarissa Meerts en Wim Huisman*
}

\begin{abstract}
'Fraudsters have been very quick to adapt well-known fraud schemes to capitalise on the anxieties and fears of victims throughout the crisis. These include various types of adapted versions of telephone fraud schemes, supply scams and decontamination scams. A large number of new or adapted fraud schemes can be expected to emerge over the coming weeks [as] fraudsters will attempt to capitalise further on the anxieties of people across Europe.'
\end{abstract}

Bovenstaand citaat komt uit een persbericht op de website van Europol, ${ }^{1}$ waarin wordt ingegaan op de te verwachten gevolgen van de wereldwijde uitbraak van het coronavirus voor ernstige criminaliteit, waaronder fraude. In deze bijdrage zullen wij ons specifiek richten op de mogelijke relaties tussen de coronacrisis en fraude en andere financieel-economische criminaliteit.

In Huismans bijdrage aan het themanummer van Justitiële verkenningen over de kredietcrisis, ruim tien jaar geleden, legde hij de lezers een aantal scenario's voor (Huisman 2009). Met deze scenario's verkende hij de mogelijke causale relaties tussen de kredietcrisis en de drie onderzoeksobjecten van de criminologie: criminaliteit, criminalisering en criminaliteitsbestrijding (Van Dijk e.a. 2018). Deze relaties sluiten elkaar niet uit, omdat crisis als gevolg van criminaliteit bijvoorbeeld kan leiden tot nieuwe criminalisering, zoals in het geval van de kredietcrisis (Levi 2008). Omdat de kredietcrisis zich binnen de financiële sector voltrok, richtte Huisman zijn scenario's op organisatiecriminaliteit (criminaliteit door en binnen wettige organisaties).

* Dr. C. Meerts is als universitair docent Criminologie verbonden aan de Vrije Universiteit Amsterdam. Dr. W. Huisman is hoogleraar Criminologie aan de Vrije Universiteit Amsterdam.

1 Europol, How criminals profit from the COVID-19 pandemic press release, 27 maart 2020, zie www.europol.europa.eu/newsroom/news/how-criminals-profit-covid-19-pandemic. De aanleiding voor het persbericht was de verschijning van het Europol-rapport Pandemic profeteering. How criminals exploit the Covid-19 crisis (maart 2020). 
$\mathrm{Nu}$, in een tijd waarin het sociale leven op ongekende wijze op zijn kop is gezet, en de coronacrisis ook wordt geassocieerd met fraude en andere financieel-economische criminaliteit, lijkt het ons waardevol om naar deze scenario's terug te keren. De scenario's kunnen helpen de diverse in de media gerapporteerde en met de coronacrisis geassocieerde gevallen van financieel-economische criminaliteit te ordenen en te duiden met oog op nader onderzoek en op aanpak. ${ }^{2}$ Door te leren van vorige crisis kunnen we een negatieve bijdrage van fraude aan de onvermijdelijke economische recessie als gevolg van de pandemie proberen te beperken. Hoewel de omstandigheden uiteraard verschillen (de kredietcrisis was immers deels veroorzaakt door fraude), is het interessant om de coronacrisis te bekijken met een 'fraudebril' op. De vier scenario's waar Huisman (2009, p. 27) het over heeft zijn:

1. De crisis is (mede) veroorzaakt door gevallen van organisatiecriminaliteit.

2. De crisis leidt tot gevallen van organisatiecriminaliteit.

3. De crisis leidt tot de criminalisering van meer ondernemingsgedrag.

4. Door de crisis zal meer organisatiecriminaliteit aan het licht komen.

In het navolgende zullen wij ingaan op deze vier scenario's. Wij passen bovenstaande scenario's enigszins aan, door ons te richten op financieel-economische criminaliteit in plaats van (alleen) op organisatiecriminaliteit.

\section{Scenario 1: de crisis is (mede) veroorzaakt door gevallen van financieel-economische criminaliteit}

Terwijl de kredietcrisis werd veroorzaakt door fraude met sub-prime hypotheken in de VS en daarvan afgeleide financiële producten (Nguyen e.a. 2010), ligt een direct causaal verband tussen financieeleconomische criminaliteit en de coronacrisis niet voor de hand.

2 Daarbij dient te worden opgemerkt dat er op dit moment nog geen wetenschappelijk onderzoek is gepubliceerd over tijdens coronacrisis gepleegde financieel-economische criminaliteit. Onderzoekers beschikken daarmee over niet veel meer dan de in de media beschreven gevallen. Bovendien gaat het hier op zijn best om verdenkingen en is er nog niemand voor aan corona gerelateerde financieel-economische criminaliteit veroordeeld. De eerste aanhangig gemaakte zaak betreft grootschalige mondkapjesfraude, waarin het Openbaar Ministerie celstraffen van vier en drie jaar eiste tegen de twee verdachten, zie bijvoorbeeld https://nos.nl/artikel/2337566-celstraffen-geeist-tegen-twee-mannen-voormondkapjesfraude.html). 
Ondanks complottheorieën over de productie van het virus in een Chinees laboratorium, is het bestaan van COVID-19 niet veroorzaakt door een vorm van fraude. Het is wel mogelijk dat de gezondheidscrisis die op de wereldwijde uitbraak is gevolgd mede het gevolg is van frauduleus handelen door organisaties en mensen met een machtspositie. De vraag is echter of we het hier hebben over criminaliteit, onhandig gedrag, of onethisch maar rechtmatig gedrag (lawful but $a w f u l$, zie Passas 2005). Het laat ingrijpen van regeringen en organisaties zal in veel gevallen eerder vallen onder de tweede (en derde) categorie dan onder de eerste.

Terwijl ondernemingen of andere organisaties de coronacrisis niet hebben veroorzaakt, kunnen hun handelingen de crisis wel verergeren. Omdat overheden hun eigen gedrag niet snel zullen criminaliseren, kiezen criminologen bij de definitie van state crime vaak niet voor op de wet gebaseerde definities van criminaliteit. Het gaat dan eerder om socially injurious action (Friedrichs 2009).

Activiteiten of bewuste nalatigheid van overheden, overheidsfunctionarissen en regeringsleiders die een bestrijding van de pandemie in de weg staan, kunnen hieronder vallen. De toekomst zal leren of de verwijten dat China het ontstaan van de pandemie heeft proberen te verhullen, dat president Trump te lang heeft volgehouden dat zijn regering de uitbraak onder controle had en dat president Bolsenaro de ernst van het virus ontkende, worden gedefinieerd als voorbeelden van staatscriminaliteit. En ook ondernemingen kunnen verwijten treffen dat zij - lawful but awful - bedrijfsbelang boven volksgezondheid hebben geplaatst, zoals de aanvankelijke weigering van Roche om het recept van de vloeistof voor het ontwikkelen van coronatests te delen. ${ }^{3}$ Hierover meer onder scenario 3 .

\section{Scenario 2: de crisis leidt tot gevallen van financieel-economische criminaliteit}

Dit scenario is waarschijnlijker. Criminologische theorieën zoals de gelegenheidstheorie (Wilcox \& Cullen 2018), benadrukken dat een toename van gelegenheden kan leiden tot een toename van criminaliteit. Een crisis als die rondom corona, waarin een tekort is aan specifieke

3 Algemeen Dagblad, 27 maart 2020, te vinden op: https://www.ad.nl/binnenland/gebouwcoronatestmaker-roche-in-almere-beklad-met-tekst-hoeveel-doden afe34f3a/. 
producten, zoals mondkapjes en desinfecterende handgel, biedt mogelijkheden tot misbruik. Voorbeelden uit de media zijn woekerprijzen voor mondkapjes ${ }^{4}$ en het leveren van ondeugdelijke of namaakmondkapjes. Op 22 februari, nog voor de uitbraak van corona in Nederland, bericht nos.nl dat een Nederlands bedrijf van oplichting wordt beticht rondom de verkoop van mondkapjes aan China. ${ }^{5} \mathrm{Op}$ 24 maart 2020 meldt de Nationale Politie daarnaast dat zij heeft kunnen voorkomen dat Nederlandse ziekenhuizen bij de aankoop van mondkapjes voor tientallen miljoenen euro's zouden worden opgelicht. ${ }^{6} \mathrm{CNN}$ deed bericht van websites waarop geneesmiddelen tegen corona worden aangeboden. ${ }^{7}$ Het zijn slechts enkele voorbeelden.

Het is treffend dat Sutherland, die het begrip 'witteboordencriminaliteit' heeft geïntroduceerd in zijn boek over de misdaden van grote ondernemingen al een heel deel besteedde aan het profiteren van de sterk toegenomen vraag en het ontbreken van tijd voor deugdelijke aanbestedingsprocedures tijdens de Eerste en Tweede Wereldoorlog. Gevolg was dat diverse bedrijven ondeugdelijke producten en grondstoffen gingen leveren die nodig waren voor de oorlogsindustrie en woekerprijzen gingen vragen (Sutherland 1949). De huidige economie ten tijde van corona is door economen al vergeleken met een oorlogseconomie. $^{8}$

We vinden in de media echter ook voorbeelden van andere vormen van financieel-economische criminaliteit in de tijd van corona, zoals handel met voorkennis. Hoewel dit vanuit een gelegenheidsperspectief kan worden bekeken, kunnen we hier ook de 'straint'heorieën op los laten: een gevoelde of verwachte spanning (bijvoorbeeld geanticipeerd verlies van welvaart) kan leiden tot crimineel gedrag om deze strain te vermijden (Agnew \& Brezina 2010). Een voorbeeld hiervan is het misbruik van voorwetenschap door Amerikaanse senatoren die op basis van geheime kennis over het coronagevaar aandelen verkochten

4 Nieuwsuur, 24 maart 2020, zie https://nos.nl/nieuwsuur/artikel/2328187-ziekenhuizenbijna-voor-tientallen-miljoenen-opgelicht-bij-aankoop-mondkapjes.html.

5 Zie https://nos.nl/artikel/2324114-nederlands-bedrijf-beticht-van-oplichting-bij-verkoopmondkapjes-voor-china.html.

6 Zie https://nos.nl/nieuwsuur/artikel/2328187-ziekenhuizen-bijna-voor-tientallenmiljoenen-opgelicht-bij-aankoop-mondkapjes.html.

7 Zie https://edition.cnn.com/2020/03/28/europe/spain-coronavirus-black-market-gougersintl/index.html.

8 Zie www.rtlz.nl/algemeen/buitenland/artikel/5065681/italiaanse-economie-stilgelegdcorona-covid19-noodmaatregel. 
of aankochten (zoals senator Loeffler, die naast het verkopen van aandelen, ook aandelen aanschafte van thuiswerk-software maker Citrix). Het lijkt er op dat zij hun voorkennis voor eigen gewin hebben ingezet, terwijl zij tegelijkertijd richting het Amerikaanse publiek uitdroegen dat alles onder controle was. ${ }^{9}$

De Autoriteit Financiële Markten (AFM) en de Europese Bankautoriteit (EBA) waarschuwen daarnaast voor nieuwe vormen van witwassen en financieren van terrorisme tijdens de coronacrisis. ${ }^{10}$ Het verleden bewijst volgens de EBA dat criminelen in tijden van crisis hun activiteiten op dit gebied regelmatig opvoeren en nieuwe technieken ontwikkelen voor onder meer witwassen. Volgens de EBA zijn er al aanwijzingen van verhoogde niveaus van cyber crime, corona-gerelateerde fraudes en oplichtingspraktijken gericht op kwetsbare personen en bedrijven en valse donatiewervingscampagnes. ${ }^{11}$

Ten slotte kan op basis van de criminologische 'strain'-theorie worden voorspeld dat bedrijven in nood wettelijke regels gaan overtreden om kosten te besparen of alternatieve bronnen van inkomsten te vinden. Dit kan leiden tot fraude en andere criminaliteit (Agnew e.a. 2009). Ondernemers in geldnood lopen extra risico om ingepalmd te worden door criminelen voor gebruik van lege bedrijfsruimtes voor drugslabs, fictieve omzet om wit te wassen en het verkrijgen van zwarte leningen. De nood van ondernemers biedt gelegenheid voor georganiseerde criminaliteit, zo laten voorbeelden uit Italië zien. ${ }^{12}$

Zowel economische hoogconjunctuur als economische laagconjunctuur zijn geassocieerd aan verhoogde niveaus van fraude (Simpson \& Rorie 2016). Tijdens momenten van economische recessie zien we bijvoorbeeld dat er sterke druk op bedrijven bestaat om financiële doelen te bereiken en dat er tegelijkertijd een situatie ontstaat waarin het externe toezicht minder strikt wordt, vanwege zorgen over de economie en bezuinigingen bij toezichthouders (Simpson \& Rorie 2016). Accountants hebben al gewezen op de fraudegevoeligheid van de Noodmaatregel Overbrugging Werkgelegenheid waarmee de overheid

9 De Volkskrant 20 maart 2020, zie www.volkskrant.nl/nieuws-achtergrond/republikeinsesenatoren-verkochten-grote-aandelenpakketten-met-voorkennis-overcoronavirus $\sim$ bd290d4b/?referer $=$ https $\% 3 \mathrm{~A} \% 2 \mathrm{~F} \% 2 \mathrm{Fwww}$.google.com $\% 2 \mathrm{~F}$.

10 Accountancy Vanmorgen, 1 april 2020, zie www.accountancyvanmorgen.nl/2020/04/01/ corona-afm-let-juist-nu-op-nieuwe-vormen-van-witwassen/.

11 European Banking Authority, zie https://bit.ly/37vnAwX.

12 NRC 8 april 2020, zie https://www.nrc.nl/nieuws/2020/04/08/maffia-deelt-in-deze-crisisgeld-uit-de-rekening-komt-later-wel-a3996216. 
ondernemers voor faillissement probeert te behoeden. ${ }^{13}$ Sinds het uitbreken van de coronacrisis zijn bij de Inspectie Sociale Zaken en Werkgelegenheid (SZW), de Financial Intelligence Unit (FIU) en de UWV ruim tweehonderd meldingen ontvangen over mogelijke fraude met steunmaatregelen van de overheid. ${ }^{14}$

Behalve een motief kunnen de omstandigheden dus ook gelegenheid geven voor het plegen van financieel-economische criminaliteit, bijvoorbeeld door een afname van toezicht. De Europese autoriteit voor effecten en markten (ESMA) heeft bijvoorbeeld al aangekondigd dat nationale toezichthouders soepeler mogen omgaan met de regels voor ondernemingen die door de coronacrisis niet voor 1 mei hun financiële verslaggeving kunnen publiceren. ${ }^{15}$ Volgens de AFM heeft de verspreiding van het coronavirus forse implicaties voor de financiële markten. Vanwege de uitzonderlijke omstandigheden waarmee de financiële sector momenteel wordt geconfronteerd, heeft de AFM besloten grote gegevensuitvragen aan financiële ondernemingen op te schorten. De AFM wil de financiële sector hiermee ruimte geven om zich volledig te richten op de uitdagingen van deze crisis en op de behoeften van de klanten. Hierop zijn enkele uitzonderingen, waaronder de naleving van de Wet ter voorkoming van witwassen en financieren van terrorisme (Wwft). Maar ook bij die onderzoeken zal de AFM rekening houden met de omstandigheden waarmee financiële ondernemingen momenteel te maken hebben. ${ }^{16}$

\section{Scenario 3: de crisis leidt tot de criminalisering van meer ondernemingsgedrag}

In crisissituaties is het gemakkelijk om hoge prijzen te vragen voor gewilde artikelen (denk aan de eerder genoemde woekerprijzen voor mondkapjes). Hoewel dit niet gewenst is, gaat het hier niet (altijd) om crimineel gedrag. De sociale reactie op dit soort gedrag is echter interessant. Zo geeft het Openbaar Ministerie aan hard op te zullen treden

13 Financieel Dagblad 24 april 2020, zie https://fd.nl/ondernemen/1342132/ fraudegevoeligheid-now-subsidie-leidt-tot-onrust-onder-accountants.

14 De Accountant 15 juni 20120, zie https://www.accountant.nl/nieuws/2020/6/200meldingen-van-mogelijke-fraude-met-coronasubsidies/.

15 Zie www.esma.europa.eu/sites/default/files/library/esma80-187-546_public_ statement_external_audit_bmr_april_2020.pdf.

16 AFM, AFM schort uitvragen deels op tot 1 juni, 26 maart 2020, zie www.afm.nl/nl-nl/ professionals/nieuws/2020/mrt/afm-schort-uitvragen-deels-op-tot-1-juni. 
tegen mensen die misbruik maken van de situatie ${ }^{17}$ en besteedden media veel aandacht aan farmaceut Roche, de marktleider voor de machines waarmee de tests voor het coronavirus worden uitgevoerd. Door de grote vraag was het voor Roche niet mogelijk voldoende materiaal te leveren waardoor de tests niet konden worden uitgevoerd. Een van de materialen, een speciale vloeistof, kan door de laboratoria zelf worden gemaakt - Roche weigerde in eerste instantie echter het geheime recept prijs te geven (Follow the Money 2020). Onder andere omstandigheden wordt dergelijk gedrag vaak niet als crimineel gezien. Mocht het, in dit voorbeeld, strafbaar worden om in een dergelijke situatie bedrijfsgeheimen geheim te houden, dan kunnen we spreken van een situatie waarin de formele criminalisering (in de wet) van het gedrag volgt op een informele criminalisering ervan (maatschappelijke verontwaardiging). Waar dit voor veel crimineel gedrag een veelvoorkomende volgorde is, komt het criminaliseringsproces in de wereld van organisatiecriminaliteit echter vaker andersom tot stand (Huisman 2009). De vraag is dus ten zeerste of dit het geval zal zijn. Toch zien we in de coronacrisis tekenen van maatschappelijke onrust over het gedrag van bedrijven ontstaan. Om bij het voorbeeld van Roche te blijven: een Nederlandse vestiging van de farmaceut is beklad met de tekst 'Hoeveel doden?'. ${ }^{18}$

Levi (2008) stelt dat er voor het criminaliseren van financieel wangedrag echter meer nodig is dan maatschappelijke onrust. Hij stelt dat een morele paniek noodzakelijk is, een buitenproportionele uitbarsting van maatschappelijke angstreacties gericht op vermeende daders (Cohen 2011), maar dat morele paniek niet snel ontstaat rondom financieel-economische criminaliteit. Hoewel veel van Levi's argumenten ook gelden in de huidige coronacrisis (bijvoorbeeld dat er vanuit de politiek juist geen behoefte is aan grootschalige onrust), zien wij wel een verschil met de kredietcrisis: waar we normaliter van financieel-economische criminaliteit inderdaad kunnen aannemen dat deze minder bedreigend is voor individuele burgers dan commune criminaliteit, gaat de coronacrisis over de volksgezondheid. Dit is iets wat de samenleving, en de mensen daarin, direct en persoonlijk raakt. Hoewel wij dus wel de door Levi aangehaalde politieke strategie van

17 NOS, 25 maart 2020, zie https://nos.nl/artikel/2328299-om-zware-straffen-en-snelrechtvoor-misbruikers-van-coronacrisis.html..

18 AD, 27 maart 2020, zie www.ad.nl/binnenland/gebouw-coronatestmaker-roche-in-almerebeklad-met-tekst-hoeveel-doden afe34f3a/.. 
risicomanagement verwachten en ook al terugzien in de aanpak van fraude in de coronacrisis, kunnen wij wellicht ook rekenen op een morele paniek. Dit laatste is echter wel deels afhankelijk van de vraag in hoeverre er echte 'folk devils' (vijanden van het volk) kunnen worden geïdentificeerd als focuspunt voor de morele paniek. Hoewel, zoals Huisman (2009) aangeeft, de (voornamelijk) mannen in de witte boorden niet aan ons traditionele boefbeeld voldoen, is dit beeld sinds de kredietcrisis wel aan enige verandering onderhevig. De bankensector, de accountancy, maar ook de farmaceutische industrie lijken al een tijdje te lijden onder een reputatieprobleem. En oplichters en ondernemers die uit winstbejag de veiligheid van zorgmedewerkers, breed gezien als de 'helden' van de huidige crisis, op het spel zetten, kunnen als 'coronahufters' rekenen op de toorn van het volk en het strafrechtelijk apparaat.

\section{Scenario 4: door de crisis zal meer financieel-economische criminaliteit aan het licht komen}

De kredietcrisis van 2008 leidde onder meer tot de ontdekking van piramidespellen (zoals die van Madoff) en andere vormen van beleggingsfraude (Huisman 2009). Zolang er meer inleg is dan uitgaven zal een piramidespel kunnen overleven. Op het moment dat dit echter niet meer het geval is, en de inleg opdroogt en investeerders hun geld opeisen, zal het piramidespel aan het licht komen. De verregaande maatregelen die op dit moment over de hele wereld worden genomen zullen naar verwachting een groot effect hebben op de wereldwijde economie. Veel bedrijven hebben reeds bij de overheid aangeklopt voor steun. In een recente publicatie over economische scenario's stelt het Centraal Plan Bureau te verwachten dat de economie hard zal worden geraakt (CBP 2020). Het is nog te vroeg om hier veel over te zeggen, maar wij kunnen wel de verwachting uitspreken dat een dergelijke economische crisis gevallen van financieel-economische criminaliteit aan het licht zal brengen.

Zoals gezegd is ook hoogconjunctuur geassocieerd aan hogere niveaus van fraude. Tijdens hoogconjunctuur worden investeerders overmoedig en verwachten ze hoge opbrengsten terwijl ze minder kritisch zijn ten aanzien van informatiebronnen die gouden bergen beloven.

Volgens Davidson (2011) is het risico op fraude twee jaar voor en na 
een economische piek hoog en wordt het steeds moeilijker de hoog gespannen verwachtingen van investeerders waar te maken. Opgeblazen, 'bull' markten verleiden gevestigde, bonafide spelers om excessieve risico's te nemen, terwijl deze markten ook malafide spelers aantrekken. Beide scenario's kunnen leiden tot frauduleuze praktijken die de markten verder doen imploderen (Simspon en Rorie 2016).

Vlak voor het toeslaan van de coronacrisis was sprake van hoogconjunctuur. Het valt dus te verwachten piramide-achtige en frauduleuze beleggingsconstructies in de problemen komen nu het de initiatiefnemers niet meer lukt nieuw geld aan te trekken met hun wervende verkooppraktijken.

\section{Afsluitend}

We zitten momenteel midden in de situatie die we beschrijven. Bovenstaande bespiegelingen zijn dan ook niet meer dan 'educated guesses'. De toekomst zal moeten uitwijzen wat de coronapandemie voor effecten heeft gehad op het gebied van fraude en andere financieel-economische criminaliteit. Het lijkt er nu in elk geval op dat de coronacrisis motivaties en gelegenheden biedt voor fraude, waaronder nieuwe vormen. De voorzitter van het College van Procureurs-Generaal heeft aangekondigd dat criminelen die misbruik maken van de coronacrisis met supersnelrecht zullen worden berecht en zware gevangenisstraffen tegen zich zullen horen eisen. ${ }^{19}$ Ondanks dit supersnelrecht zal een zelf ook door de crisis getroffen strafrechtelijk apparaat nog wel jaren bezig zijn met de strafrechtelijke nasleep. De coronacrisis is niet voorbij wanneer iedereen is gevaccineerd. Door uitgestelde behandelingen zal de crisis in de gezondheidszorg voortduren. Het Centraal Plan Bureau voorspelt dat de economische gevolgen van de coronacrisis nog jaren lang voelbaar zijn. Dat kan dus ook gelden voor samenhangende financieel-economische criminaliteit. Net als na de kredietcrisis kan verwacht worden dat er nog lang onderzoek zal worden gedaan en gepubliceerd worden over criminaliteit en de coronacrisis (Will e.a. 2013).

19 NOS, 25 maart 2020, zie https://nos.nl/artikel/2328299-om-zware-straffen-en-snelrechtvoor-misbruikers-van-coronacrisis.html. 


\section{Literatuur}

\section{Agnew e.a. 2009}

R. Agnew, N. Leeper Piquero \& F.T. Cullen, 'General Strain Theory and White- Collar Crime', in: D. Weisburd \& S. Simpson (eds.), The Criminology of WhiteCollar Crime, New York: Springer 2009, p. 35-60.

\section{Agnew \& Brezina 2010}

Agnew, R., \& Brezina, T., 'Strain theories', in: E. McLaughlin \& T. Newburn (eds.), The Sage Handbook of Criminological Theory, Thousand Oaks: Sage Publications 2010, p. 96-113.

\section{CBP 2020}

CBP, Economische scenario's corona, Den Haag: Centraal Planbureau 2020. www.cpb.nl/sites/ default/files/omnidownload/ CPB-Infographic-Economischescenarios-corona-26mrt2020.pdf.

\section{Cohen 2011}

S. Cohen, Folk devils and Moral panics. The creation of the Mods and Rockers, Abingdon, Oxon: Routledge 2011.

\section{Davidson 2011}

R. Davidson, Accounting Fraud: Booms, Busts, and Incentives to Perform, Chicago: The University of Chicago 2011.

\section{Europol 2020}

Europol, Pandemic profeteering. How criminals exploit the Covid-19 crisis. Den Haag: Europol 2020.

www.europol.europa.eu/ publications-documents/ pandemic-profiteering-howcriminals-exploit-covid-19-crisis Follow the Money 2020

Follow the Money, “"Testen, testen, testen" - alleen als het farmaceut Roche behaagt', 27 maart 2020, www.ftm.nl/artikelen/ roche-corona-lysisbuffer.

\section{Friedrichs 2009}

D.O. Friedrichs, Trusted Criminals: White-Collar Crime in Contemporary Society, Belmont, CA: Wadsworth Cengage Learning 2009.

\section{Huisman 2009}

W. Huisman, 'Kredietcrisis en organisatiecriminaliteit: vier mogelijke relaties', Justitiële Verkenningen (35) 2009-6, p. 26-42.

\section{Levi 2008}

M. Levi, 'Suite revenge? The shaping of folk devils and moral panics about white-collar crimes', British Journal of Criminology, (48) 2008, p. 1-20. 


\section{Nguyen e.a. 2010}

T.H. Nguyen \& H.N. Pontell, 'Mortgage Origination Fraud and the Global Economic Crisis', Criminology \& Public Policy (9), p. 591-612.

\section{Passsas 2005}

N. Passas, 'Lawful but awful: 'Legal Corporate Crimes', The Journal of Socio-Economics (34) 2005-6, p. 771-786.

\section{Simpson \& Rorie 2016}

S.S. Simpson \& M. Rorie, 'Economic Fluctuations and Crises', in: S. Van Slyke, M. Benson \& F.T. Cullen (eds.), Oxford Handbook of White-Collar Crime, Oxford: Oxford University Press 2016, p. 326-344.

\section{Sutherland 1949}

E.W. Sutherland, White Collar

Crime, New York: Dryden 1949.

\section{Van Dijk e.a. 2018}

J. van Dijk, W.Huisman \&

P. Nieuwbeerta, Actuele criminologie, Den Haag: Sdu uitgevers 2018.

\section{Wilcox \& Cullen 2018}

P. Wilcox \& F.T. Cullen, 'Situational opportunity Theories of Crime', Annual review of Criminology (1) 2018-1, p. 123-148.

\section{Will e.a. 2013}

S. Will, S. Handelman \& D.C. Brotherton (eds), How They Got Away With It: White collar Criminals and the Financial Meltdown, New York: Columbia University Press 2013. 